\title{
Indonesian Government's COVID-19 Measures, January-May 2020: Late Response and Public Health Securitization
}

\author{
Tangguh Chairil \\ Department of International Relations, Bina Nusantara University \\ (email: tangguh@binus.ac.id)
}

\begin{abstract}
The Indonesian government's measures to control the coronavirus disease 2019 (COVID-19) pandemic can be characterized by late response due to initial de-securitization of the issue, and later securitization that limits its very efficacy in restricting the spread of the pandemic. This article uses securitization theory to analyze the government's measures to control the COVID-19 pandemic and discusses how the government's increasing reliance on military figures and national security agencies influences the measures used to control the COVID-19 pandemic. This study finds that initially, the government seemed to be trying to de-securitize the issue, denying warnings that the virus might have existed undetected in Indonesia. Then, after the first cases were confirmed in March 2020, the government responded by securitizing the issue. The delay in the government's response to COVID-19 caused the audience to not fully accept the government's securitization efforts because public trust in the government's measures was already low, while the means of emergency action taken by the government against the threat of COVID-19 are also limited. The government has also been overly reliant on influential military figures and national security agencies. The government also tended to downgrade the threats, lack transparency, and even use the pandemic to crack down on anti-government smears. This article concludes that the government needs to change their approach to COVID-19 measures and prioritize the human security dimension by not downgrading the threats and upholding transparency.
\end{abstract}

Keywords:

coronavirus; COVID-19; public health security; Indonesia; securitization

\section{Introduction}

As the coronavirus disease 2019 (COVID-19) pandemic spread to Indonesia, there are notes which can be taken from the Indonesian government's handling of the pandemic. First, until February 2020, the Indonesian government seemed to be attempting to de-securitize the issue, denying warnings that the virus might have already existed undetected in Indonesia. The Minister of Health, Terawan Agus Putranto (hereinafter Terawan) infamously told the public not to panic over the virus and "just 'enjoy' it" (Warta Ekonomi, 2020, January 27). Other government officials also made public statements which underestimated the COVID-19 issue, some of which this article presents in the results section. In this period, the government seemed more concerned of the economic impacts, as the President Joko Widodo (hereinafter Jokowi) announced that the government was considering providing incentives for the tourism and aviation industry (Presiden RI, 2020, February 17).

Second, only since the first cases were confirmed in March 2020 has the Indonesian government responded by securitizing the issue. In terms of public health measures, the government announced the implementation of large-scale social restrictions (PSBB) and strict 
physical distancing to restrict the spread of the pandemic. Meanwhile, in terms of economic mitigation, the government announced several social protections, tax stimulus, and other economic measures. Despite the restrictions, by April the pandemic had spread to all 34 provinces.

Third, so far, the Indonesian government's measures to the pandemic has apparently relied on influential military figures - both retired generals in the Cabinet and active officers in national security agencies. The Minister of Health, Terawan, was a military doctor. The government's COVID-19 Mitigation Acceleration Task Force is led by the Chief of the National Disaster Management Agency (BNPB), Lt. Gen. Doni Monardo (hereinafter Doni), who is an active three-star general. Other military figures fill up the positions in the government's COVID-19 measures. However, the reliance on military figures seemed not to correlate with the human security dimension of the pandemic, as the government could not restrict the spread of the pandemic and the number of cases and death keeps rising.

This article thus discusses the Indonesian government's measures to the COVID-19 pandemic in January to May 2020 using securitization (and de-securitization) theory in International Relations. The author chose to use this theory because it provides a useful tool to analyze the dynamics of the government's COVID-19 measures: The initial lack of response to the pandemic is seen as the government's de-securitizing attempts, while the emergency measures conducted after the first confirmed cases is viewed as securitization of the pandemic. Securitization theory also enables examining the government's communication about the COVID-19 pandemic, which initially tended to underestimate the issue.

The author chose the period of JanuaryMay 2020 to provide a timely comparison between before the official confirmation of the pandemic in Indonesia (January-February 2020) and after the pandemic began in the country (since March 2020). The author chose to study only three months after the start of the pandemic (March-May 2020) because the onset of the pandemic response is considered the best period to note the drastic shift from the normal/ non-emergency politics to the government's emergency measures.

The structure is as follows: This article first reviews literature on securitization (and militarization, as the concept which is often linked with securitization), then focusing on the securitization of public health issues. This article then reviews literature on the Indonesian government's increasing reliance on military figures, before discussing how these military figures influence the government's measures to the COVID-19 pandemic. Finally, this article discusses the government's COVID-19 measures using securitization theory. The author expects that this article contributes to the understanding that the government needs to change its security-heavy approach to the pandemic, as it is a public health issue.

\section{Literature Review \\ Securitization Theory}

Securitization theory was developed by Copenhagen School scholars, such as Barry Buzan, Ole Wæver, and Jaap de Wilde, who are mainly concerned on how security is socially constructed in international politics, and the extent to which political actors view and construct certain issues as security threats. Securitization theory examines the process in which actors declare certain issues as "existential threats" to a certain referent object. If accepted by the audience, the securitization process allows the state to suspend normal political methods and use emergency measures in response to the crisis. In this sense, security is a place of negotiation between securitizing actors and the audience (Wæver, 1995; McSweeney, 1996; Buzan \& Wæver, 1997; Buzan, Wæver, 
\& de Wilde, 1998; Huysmans, 1998; C. A. S. E. Collective, 2006).

In the securitization process, threats are articulated in "speech act". In this process, the securitizing actors use the language of security and threats to claim that the state needs to use whatever means necessary to block a threat. An issue is successfully securitized if the audience accepts it as an existential threat and agrees that the state needs to use emergency methods in responding to it. The audience will accept securitization if there is a series of "facilitating conditions", including the grammar of security, social capital of the securitizing actors, condition related to threat (Buzan, Wæver, \& de Wilde, 1998; Wæver, 2000), and conditions related to audience (Vuori, 2008). These conditions allow the audience to accept securitization carried out by the securitizing actors, who are usually political leaders.

According to John R. Searle (1975), Daniel Vanderveken (2002), and Juha A. Vuori, (2008), there are five types of speech acts: assertive, directive, commissive, expressive, and declaration. Assertive speech acts take forms such as statements, explanations, and assertions. Directive speech acts take forms such as orders, requests, and commands. Commissive speech acts take forms such as vows, threats, and guarantees. Expressive speech acts take forms such as apologies, thanks, and congratulations. Finally, declarations take forms such as declaring war, pronouncing wedlock, and adjourning a meeting.

The opposite of securitization is desecuritization, a process in which actors keep certain issues away from the security realm and re-enter it into the normal political sphere. Once an issue is de-securitized, it will not be dealt with by security logic and not be declared a threat but returned to the ordinary public sphere. De-securitization can be done by not discussing an issue as a threat at all, managing the issue so that it does not spiral, and moving the issue back to normal politics
(Wæver, 1995; Buzan, Wæver, \& de Wilde, 1998).

According to Lene Hansen (2012), there are four forms of de-securitization: change through stabilization, replacement, re-articulation, and silencing. The first form of de-securitization is indicated by explicit change in the security discourse. Replacement is when one issue is excluded, while another is securitized. Rearticulation is indicated by the offering of a political solution to the threat and addressing the source of conflict. Finally, silencing is when an issue disappears or does not register in a security discourse.

\section{Securitization and Militarization}

A concept that is often linked with securitization is militarization, in terms of the emergency methods used by the state to respond to an existential threat. While the emergency methods are not entirely and focused only on military means, some of the ways the state uses to block a threat are indeed military mobilization. To avoid equalizing securitization with militarization, it is necessary to define militarization.

Scholars have defined militarization as "military build-up". M. V. Naidu (1985), for example, defines militarization as "the gathering of arms, the raising of armies, the seeking of military bases and allies, etc.". Andrew L. Ross (1987) differentiate two forms of militarization: the first one is "the process ... that results in militarism" and the second one is "military build-up". Similar to Ross' second form of militarization, Alexander Wendt and Michael Barnett (1993) define militarization as "the accumulation of capacity for organized violence". Julian Schofield (2007, p. 11) defines militarization as "the measure of the extent of use of military structures and procedures in a state's decision-making process". Peter B. Kraska (2007) defines militarization as "the implementation of the ideology [of] militarism", "the process of arming, organizing, planning, 
training for, threatening, and sometimes implementing violent conflict".

Scholars have suggested that a high degree of militarization of a state's government increases the likelihood of war and results in a less effective strategy. According to Schofield (2007, p. 11), it results in a less effective strategy due to favoring the military over other state instruments. Schofield further argues that the militarization of a state's decision-making process occurs when the military, or those with a military perspective, gain relatively greater influence while the civilian policymaking institutions gain relatively less influence. Thus, the state's leadership becomes increasingly sensitive to a military perspective on policy issues.

After defining militarization, we can see the relations between securitization and militarization. Setenay Yağanoğlu (2006, pp. 24-30) has summed it up well: In militarist states where the government and society has been militarized, when an issue is securitized, it is easier for the people as audience to expect military means to be used to deal with the situation and to accept this choice, with little to no room to question its rationality. On the other hand, security becomes the justification label for military means to be used in the first place when dealing with security issues. Therefore, according to Yağanoğlu (2006, pp. 24-30), the relations between securitization and militarization is like "chicken and egg". This is because securitization is fed from militarization and enables the continuation of militarization.

However, to avoid mixing the two concepts, I would point out that military buildup is not the only emergency method used by the state to respond to an existential threat. According to Rita Floyd (2015), the emergency measures refer to those measures which are not possible within non-emergency situation, either by executive unilateralism (Williams, 2003; Neal, 2010) or by the legislature passing new laws granting new authority which are not possible within existing, non-emergency legislation (Sarat, 2010). The measures can involve all state's security apparatus, not just the military.

\section{Securitization of Public Health}

One of the issues which have traditionally not been a security issue, but have been securitized, is public health. At first, scholars such as Richard Ullman (1983) redefined the concept of security more broadly to include the potential impact of a pandemic on the global economy, socio-political stability, and international relations. Then, public health security studies developed as states and international organizations inserted the human security agenda into their foreign and security policy.

Securitization of public health issues has happened due to the spread of infectious diseases, especially to the West (Pirages, 1997; Price-Smith, 2001; 2009); the impact of HIV/ AIDS, especially on the stability of the country (Elbe, 2002; Heinecken, 2003; McInnes, 2006; McInnes \& Rushton, 2010; McInnes, 2011); and the risk of bioterrorism (Garrett, 2001; Strongin \& Redhead, 2001; Graham, 2008).

Scholars have agreed that there are benefits of securitizing health issue: on the security side, public health experts bring valuable tools and expertise to a number of new problems, while on the health side, public health securitization raises its political profile leading to the prospect of greater resources devoted to urgent health needs. However, scholars also argue that securitization of public health issues is also problematic. First, it makes national security actors control the agenda of public health. Second, it leads to relatively narrow health problems which are considered as part of the national security agenda. Third, it puts national security perspective above human security dimension (Elbe, 2006; McInnes \& Lee, 2006). Therefore, despite securitization of public health issues may increase attention to health 
issues and political support for suppressing the health problems, scholars also warn against the risks of subordinating health issues to national security needs.

\section{Securitization (and Militarization) in Indonesia}

Scholars have used securitization theory to explain various cases of Indonesia's security policy, including the South China Sea disputes (Meyer, Nurmandi, \& Agustiyara, 2019), the Aceh insurgency (Geri, 2018; Kurniawan, 2018), the Maluku conflict (Kurniawan, 2018), terrorism (Van Damme, 2008; Febrica, 2010), illicit drugs (Widiyono, 2018), migrants and refugees (Zayzda, Ash-Shafikh, \& Kusuma, 2019), migrant workers (Arifianto, 2009), as well as online hoaxes (Lee, 2020). However, there is still a lack of literature on public health securitization in Indonesia, which this article seeks to fill the gap.

Related to securitization in Indonesia, scholars have also discussed the militarization of Indonesian government in post-Suharto democratic Indonesia, especially during Jokowi administration. President Jokowi has been heavily relying on active-duty and retired military figures, giving the military perspective greater influence on policy issues. The Armed Forces (TNI) has also gained relatively greater influence during Jokowi administration. TNI has been involved in non-military domains, including counterterrorism (Singh, 2016), food security, wildfire, and various other civil domains (Gunawan, 2017; Sebastian, Syailendra, \& Marzuki, 2018; Laksmana, 2019a; Laksmana, 2019b). Scholars have argued that it happened because Jokowi is a president without his own political party and therefore needs the support of a wider national security establishment to carry out his agenda (Laksmana, 2019a). This article also touches upon militarization in Indonesia, especially on how the securitization of the government's COVID-19 measures had been fed from the ongoing militarization of the government, and how the public health securitization had been enabling the continuation of the militarization.

\section{Methods}

This article discusses the Indonesian government's measures to the COVID-19 pandemic in January to May 2020 using securitization theory as discussed above. It explains how the government, as the securitizing actor, de-securitized the pandemic in January to February 2020 and then securitized the issue in March to May 2020 by looking at the speech acts and facilitating conditions in the de-securitizing and securitizing attempts.

In analyzing the speech act, this article uses content analysis to explain whether the language used by the government in the securitizing attempts are assertive, directive, commissive, expressive, and declaration, as classified by Searle (1975), Vanderveken (2002), and Vuori (2008). The author chooses to use content analysis to enable examining the patterns in the government's communication about the COVID-19 measures.

The government's communication analyzed in this study is obtained from official communication channels of the government ministries and agencies related to the COVID-19 measures, including web sites and social media:

This article also uses data from secondary sources which are publicly accessible, including media sources. To validate the data obtained from non-official government sources, the author checked the correctness and meaningfulness of all data by triangulating it with several sources. Due to self-quarantine amid social/physical distancing during the pandemic, the author did not collect primary data using surveys or interviews.

\section{Results}

\section{January to February 2020: Lack of Response}

The first COVID-19 cases in Indonesia were confirmed on 2 March 2020, but experts 
Table 1.

Sources of Government's Communication Analyzed

\begin{tabular}{|c|c|c|}
\hline Government Institutions & Web Sites & $\begin{array}{c}\text { Social Media (Twitter) of } \\
\text { Institutions and Office Holders }\end{array}$ \\
\hline President & https://www.presidenri.go.id/ & @jokowi \\
\hline Cabinet Secretariat & https://setkab.go.id/ & @setkabgoid \\
\hline $\begin{array}{l}\text { Coordinating Ministry of Political, Legal, and } \\
\text { Security Affairs }\end{array}$ & https://polkam.go.id/ & $\begin{array}{l}@ \text { PolhukamRI } \\
@ \text { mohmahfudmd }\end{array}$ \\
\hline Ministry of Health & https://www.kemkes.go.id/ & $@$ KemenkesRI \\
\hline Ministry of Transportation & http://dephub.go.id/ & $\begin{array}{l}@ \text { kemenhub151 } \\
@ \text { BudiKaryaS }\end{array}$ \\
\hline Ministry of Finance & https://www.kemenkeu.go.id/ & @KemenkeuRI \\
\hline Police (Polri) & https://www.polri.go.id/ & $@$ DivHumas_Polri \\
\hline $\mathrm{BNPB}$ & https://bnpb.go.id/ & $@ B N P B \_I n d o n e s i a$ \\
\hline $\begin{array}{l}\text { Meteorology, Climatology, and Geophysical } \\
\text { Agency (BMKG) }\end{array}$ & https://www.bmkg.go.id/ & @infoBMKG \\
\hline COVID-19 Mitigation Acceleration Task Force & https://covid19.go.id/ & \\
\hline
\end{tabular}

Source: Author

had been warning that the coronavirus might have already existed undetected in Indonesia since January. For example, in January 2020, Chairman of the Eijkman Institute for Molecular Biology in Central Jakarta, Prof. Amin Soebandrio, said that Indonesia lacked the specific reagents to detect the virus (The Age, 2020, January 31; Sydney Morning Herald, 2020, January 31). In February 2020, Chairman of the Indonesian Red Cross Society (PMI), Jusuf Kalla, said that the disease might have entered Indonesia, but Indonesian people might not recognize the symptoms (The New York Times, 2020, February 11). A study by Pablo M. De Salazar et al. (2020) also concluded that the coronavirus could have arrived in Indonesia and Cambodia due to direct flights from Wuhan during the outbreak.

However, the Indonesian government denied these warnings and tended to show no sense of crisis or even to underestimate the threat of coronavirus, until February 2020. For example, on 7 February 2020, the Coordinating Minister for Political, Legal and Security Affairs, Mahfud MD, announced that Indonesia was the only major country in Asia that did not yet have a positive case of the coronavirus (CNN Indonesia, 2020, February 7). On 11 February 2020, the Minister of Health,
Terawan, discredited the study by De Salazar et al., challenging the researchers to come to Indonesia to directly prove the results of their research (CNN Indonesia, 2020, February 11). On 26 February 2020, Vice President Ma'ruf Amin (hereinafter Ma'ruf) said that the coronavirus did not dare to come to Indonesia because of the prayers and istigasah (a form of Islamic prayer) of the ulama (Muslim scholars) (Tempo, 2020, February 27). Some of the statements that underestimated the COVID-19 issue in this period are summarized in Table 2.

In facing this public health issue, the government seemed more concerned of the economic dimension, especially of the impacts on the tourism and aviation industries. For example, on 24 February 2020, the Coordinating Minister for Economic Affairs, Airlangga Hartarto (hereinafter Airlangga), announced that the government would budget IDR 72 billion for influencers to encourage the tourism sector, IDR 98.5 billion for airlines and travel agents, IDR 103 billion for promotional activities, and IDR 25 billion for tourism activities (Liputan 6, 2020, February 26). On 25 February 2020, the Minister of Finance, Sri Mulyani, announced that the government would provide a stimulus package worth IDR 10.3 trillion, which focused on the tourism, 
Table 2.

Indonesian Government Officials' Statements Which Underestimated COVID-19 Issue, Until February 2020

\begin{tabular}{|c|c|c|c|}
\hline Date & Government Officials & $\begin{array}{c}\text { Statements } \\
\end{array}$ & Sources \\
\hline $\begin{array}{l}2020, \\
\text { January } 27\end{array}$ & Minister of Health, Terawan & $\begin{array}{l}\text { "The prevention of coronavirus is to not } \\
\text { panic and fret, just 'enjoy' it, and eat } \\
\text { sufficiently". }\end{array}$ & $\begin{array}{l}\text { Warta Ekonomi (2020, } \\
\text { January } 27)\end{array}$ \\
\hline $\begin{array}{l}2020 \\
\text { February } 07\end{array}$ & $\begin{array}{l}\text { Coordinating Minister for } \\
\text { Political, Legal and Security } \\
\text { Affairs, Mahfud MD }\end{array}$ & $\begin{array}{l}\text { "Indonesia is the only major country in } \\
\text { Asia that does not yet have a positive } \\
\text { case of the coronavirus". }\end{array}$ & $\begin{array}{l}\text { CNN Indonesia (2020, } \\
\text { February 7) }\end{array}$ \\
\hline $\begin{array}{l}2020 \\
\text { February } 11\end{array}$ & Minister of Health, Terawan & $\begin{array}{l}\text { Discredited the study that concluded } \\
\text { that the coronavirus should already exist } \\
\text { undetected in Indonesia and challenged } \\
\text { the researchers to come to Indonesia } \\
\text { to directly prove the results of their } \\
\text { research. }\end{array}$ & $\begin{array}{l}\text { CNN Indonesia (2020, } \\
\text { February 11) }\end{array}$ \\
\hline $\begin{array}{l}2020 \\
\text { February } 15\end{array}$ & $\begin{array}{l}\text { Coordinating Minister for } \\
\text { Political, Legal and Security } \\
\text { Affairs, Mahfud MD }\end{array}$ & $\begin{array}{l}\text { "The coronavirus cannot enter Indonesia } \\
\text { due to complicated licensing". }\end{array}$ & $\begin{array}{l}\text { Mahfud MD (@ } \\
\text { mohmahfudmd), (2020, } \\
\text { February 15) }\end{array}$ \\
\hline $\begin{array}{l}2020, \\
\text { February } 17\end{array}$ & $\begin{array}{l}\text { Minister of Transportation, } \\
\text { Budi Karya Sumadi }\end{array}$ & $\begin{array}{l}\text { "There is no coronavirus in Indonesia } \\
\text { because the people are immune from } \\
\text { eating nasi kucing" (an Indonesian rice } \\
\text { dish). }\end{array}$ & $\begin{array}{l}\text { Republika (2020, } \\
\text { February } 17)\end{array}$ \\
\hline $\begin{array}{l}2020, \\
\text { February } 24\end{array}$ & $\begin{array}{l}\text { Secretary of the Directorate } \\
\text { General of Disease Prevention } \\
\text { and Control of the Ministry of } \\
\text { Health, Achmad Yurianto }\end{array}$ & $\begin{array}{l}\text { Said that the Japanese citizen who tested } \\
\text { positive for the SARS-CoV-2 virus } \\
\text { after returning from a trip to Indonesia } \\
\text { was not a COVID-19 case, insisting } \\
\text { that SARS-CoV-2 was different from } \\
\text { COVID-19. } \\
\text { (Note: COVID-19 is the name of the } \\
\text { disease, while SARS-CoV-2 is the name } \\
\text { of the virus that caused it.) }\end{array}$ & $\begin{array}{l}\text { The Jakarta Post (The } \\
\text { Jakarta Post, 2020, } \\
\text { February 25) }\end{array}$ \\
\hline $\begin{array}{l}2020 \\
\text { February } 26\end{array}$ & Vice President Ma'ruf & $\begin{array}{l}\text { "The coronavirus does not dare to come } \\
\text { to Indonesia because of the prayer and } \\
\text { istigasah of the ulama, Muslim scholars". }\end{array}$ & $\begin{array}{l}\text { Tempo (2020, February } \\
\text { 27) }\end{array}$ \\
\hline $\begin{array}{l}2020 \\
\text { February } 29\end{array}$ & $\begin{array}{l}\text { Main Expert Staff of } \\
\text { Presidential Staff Office (KSP), } \\
\text { Ali Mochtar Ngabalin }\end{array}$ & $\begin{array}{l}\text { "There is no coronavirus in Indonesia } \\
\text { because it does not develop strongly in } \\
\text { tropical countries". }\end{array}$ & $\begin{array}{l}\text { Tribun News (2020, } \\
\text { February 29) }\end{array}$ \\
\hline
\end{tabular}

Source: collected from various media sources

airline, and housing sector (Kemenkeu, 2020, February 26). Some of the statements which are more concerned of economic aspects in dealing with covid-19 issues in this period are summarized in Table 3.

As discussed above, in January to February 2020 the Indonesian government seemed to be trying to de-securitize the COVID-19 pandemic, in the form of silencing. It is indicated by the fact that the issue failed to register in the government's security discourse. In fact, this article views that the government might have strived for a strategy of exclusion, when there are other security and political issues which the government needed to address. For example, in this period the government was preoccupied with tension with China in the Natuna waters, issue of repatriation of former Indonesian foreign terrorist fighters from the Middle East, flash floods throughout Jakarta metropolitan area, alleged corruption in state-owned insurance company PT Asuransi Jiwasraya, as well as the Omnibus Bill on Job Creation. As illustration of how the last example might have led the government to exclude the pandemic issue, on 15 February 2020 the Coordinating Minister for Political, Legal and Security Affairs, Mahfud 
Table 3.

Indonesian Government Officials' Statements Which Are More Concerned of Economic Aspects in Dealing with COVID-19 Issues, Until February 2020

\begin{tabular}{|c|c|c|c|}
\hline Date & Government Officials & Statements & Sources \\
\hline $\begin{array}{l}2020, \\
\text { February } 07\end{array}$ & $\begin{array}{l}\text { Special Staff of the } \\
\text { Minister of Transportation, } \\
\text { Adita Irawati }\end{array}$ & $\begin{array}{l}\text { The government had asked domestic airlines to } \\
\text { offer cheaper flight tickets to Bali, North Sulawesi, } \\
\text { and Bintan to anticipate the decline in tourists } \\
\text { from China. }\end{array}$ & $\begin{array}{l}\text { Kabar Bisnis (2020, } \\
\text { February 7) }\end{array}$ \\
\hline $\begin{array}{l}2020, \\
\text { February } 12\end{array}$ & $\begin{array}{l}\text { Minister of Transportation, } \\
\text { Budi Karya Sumadi }\end{array}$ & $\begin{array}{l}\text { The government was considering incentives for } \\
\text { the tourism and aviation industry, including } \\
\text { cutting the amount of non-tax revenue collection, } \\
\text { instructing airport authority companies PT } \\
\text { Angkasa Pura I and II to lower landing costs, and } \\
\text { calling on hotels to give room rental discounts. }\end{array}$ & $\begin{array}{l}\text { Ministry of } \\
\text { Transportation } \\
\text { (2020, February 13) }\end{array}$ \\
\hline $\begin{array}{l}\text { 2020, } \\
\text { February } 17\end{array}$ & President Jokowi & $\begin{array}{l}\text { The government was considering providing } \\
\text { incentives for tourists and travel agents. }\end{array}$ & $\begin{array}{l}\text { Presiden RI (2020, } \\
\text { February 17) }\end{array}$ \\
\hline $\begin{array}{l}\text { 2020, } \\
\text { February } 20\end{array}$ & President Jokowi & $\begin{array}{l}\text { The government decided to intensify investment } \\
\text { to spur economic growth. }\end{array}$ & $\begin{array}{l}\text { Presiden RI (2020, } \\
\text { February 20) }\end{array}$ \\
\hline $\begin{array}{l}2020, \\
\text { February } 20\end{array}$ & $\begin{array}{l}\text { Coordinating Minister for } \\
\text { Maritime and Investment } \\
\text { Affairs, Luhut Binsar } \\
\text { Pandjaitan }\end{array}$ & $\begin{array}{l}\text { Wanted foreign workers from China to return } \\
\text { to Indonesia immediately after the coronavirus } \\
\text { subsides. }\end{array}$ & $\begin{array}{l}\text { Tirto }(2020, \\
\text { February } 21)\end{array}$ \\
\hline $\begin{array}{l}2020, \\
\text { February } 20\end{array}$ & $\begin{array}{l}\text { Minister of Transportation, } \\
\text { Budi Karya Sumadi }\end{array}$ & $\begin{array}{l}\text { The government would provide financial } \\
\text { assistance measures to revitalize the economy and } \\
\text { support airline operators. }\end{array}$ & $\begin{array}{l}\text { AIN Online (2020, } \\
\text { February 20) }\end{array}$ \\
\hline $\begin{array}{l}2020, \\
\text { February } 24\end{array}$ & $\begin{array}{l}\text { Coordinating Minister } \\
\text { for Economic Affairs, } \\
\text { Airlangga }\end{array}$ & $\begin{array}{l}\text { The government would budget IDR } 72 \text { billion for } \\
\text { influencers to encourage the tourism sector, IDR } \\
98.5 \text { billion for airlines and travel agents, IDR } \\
103 \text { billion for promotional activities, and IDR } 25 \\
\text { billion for tourism activities. }\end{array}$ & $\begin{array}{l}\text { Liputan } 6(2020, \\
\text { February 26) }\end{array}$ \\
\hline $\begin{array}{l}\text { 2020, } \\
\text { February } 25\end{array}$ & President Jokowi & $\begin{array}{l}\text { The government gave discounts on plane ticket } \\
\text { prices and exempted hotel and restaurant taxes. }\end{array}$ & $\begin{array}{l}\text { Presiden RI (2020, } \\
\text { February 25) }\end{array}$ \\
\hline $\begin{array}{l}2020, \\
\text { February } 25\end{array}$ & $\begin{array}{l}\text { Minister of Finance, Sri } \\
\text { Mulyani }\end{array}$ & $\begin{array}{l}\text { The government would provide a stimulus } \\
\text { package worth IDR } 10.3 \text { trillion, which focuses on } \\
\text { the tourism, airline, and housing sector. }\end{array}$ & $\begin{array}{l}\text { Kemenkeu (2020, } \\
\text { February 26) }\end{array}$ \\
\hline
\end{tabular}

Source: collected from various media sources

MD, tweeted, "The coronavirus cannot enter Indonesia due to complicated licensing. But the Omnibus Bill on Job Creation needs to continue" (Mahfud MD (@mohmahfudmd), 2020, February 15).

Despite the initial de-securitization, there are also forms of speech acts related to the COVID-19 pandemic in this period, in the form of declaration. For example, on 28 January 2020 the Chief of BNPB, Lt. Gen. Doni, issued Chief of BNPB Decree No. A of 2020, which declared the status of coronavirus disease outbreak disaster emergency in Indonesia. Then, on 4 February 2020 the Minister of Health Terawan issued Minister of Health Decree No. HK.01.07/
Menkes/104/2020, which declared the novel coronavirus infection as a disease that could cause a plague. However, there are no other forms of speech acts (assertive, directive, nor commissive) related to the pandemic in this period which could construct the issue as a threat. Even not all the declaration is presented to the audience; for example, the Chief of BNPB Decree was only informed to the public on 17 March 2020, seven weeks after it was initially issued.

\section{March to May 2020: Public Health Securitization}

The first COVID-19 cases in Indonesia were confirmed on 2 March 2020. As of 31 May 
Figure 1.

Indonesia Cumulative COVID-19 Data (as of 31 May 2020)

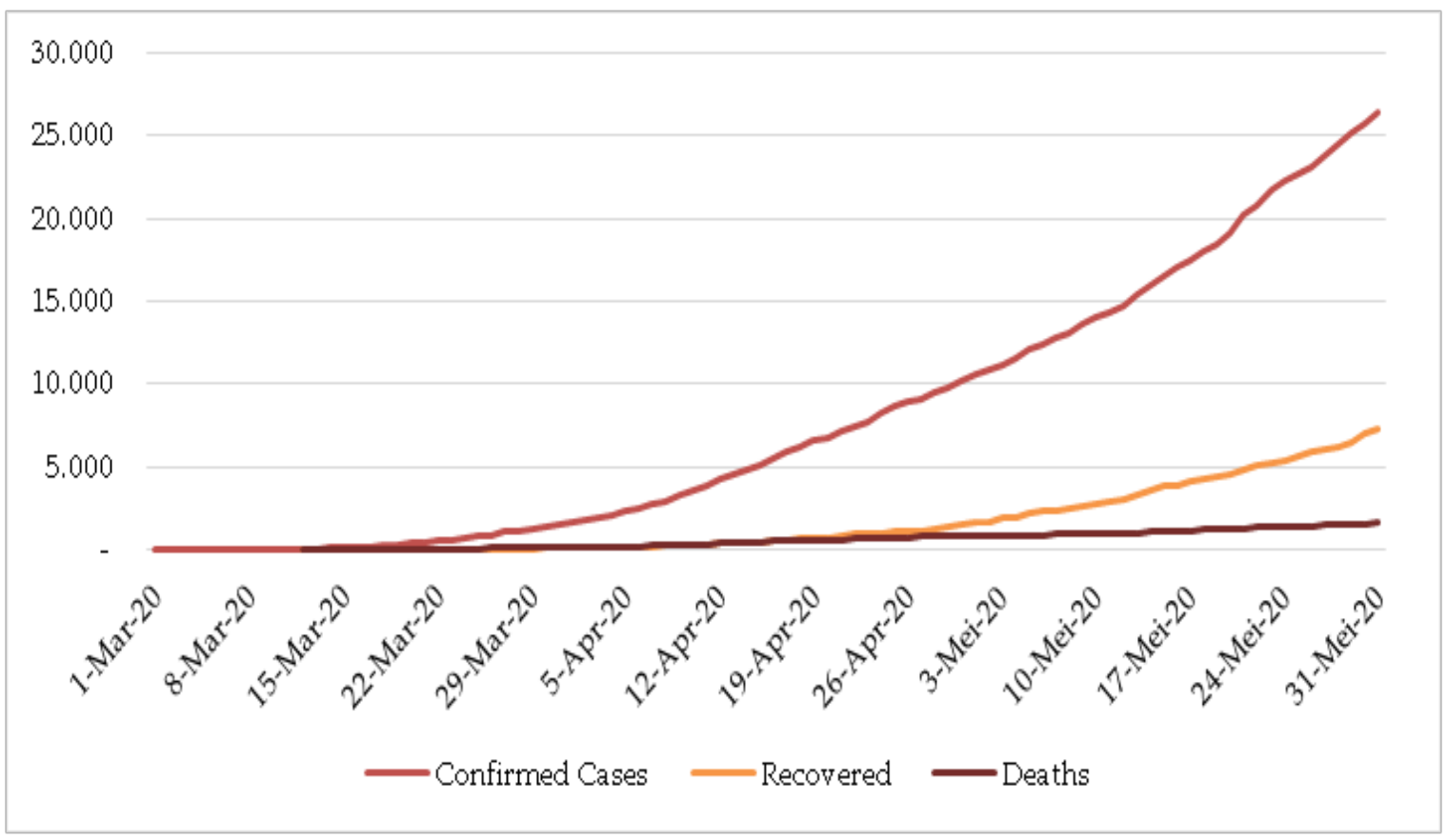

Source: COVID-19 Task Force, 2020

2020, there are 26,473 confirmed COVID-19 cases in the country, of which 7,308 have been declared cured, while 1,613 have died. The Java Island, especially Jakarta Province, is the most affected by this pandemic. However, the disease has spread to all 34 provinces.

Riyanti Djalante et al. (2020) has provided a detailed review and analysis of the responses to COVID-19 in Indonesia from January to March 2020, including the government's, non-governmental organizations' and the community's responses. In reporting the government's response, Djalante et al. includes all related government ministries and agencies: the COVID-19 Mitigation Acceleration Task Force, National Disaster Management Agency (BNPB), Ministry of Health, Ministry of Finance, Bank Indonesia (BI), TNI, Polri, as well as Ministry of Villages, Development of Disadvantaged Regions, and Transmigration. While Djalante et al.'s article discusses the overall government's COVID-19 measures, this article focuses on the measures which might be seen as the emergency measures in the securitization of COVID-19, including health response and economic mitigation, in March to May 2020.

In terms of health response, the government is implementing large-scale social restrictions (PSBB) and strict physical distancing to restrict the spread of the pandemic. PSBB is regulated in the Minister of Health Regulation No. 9 of 2020, which was issued on 3 April 2020. Governors or regents and mayors can propose PSBB in their regions to the Minister of Health for approval. By 31 May 2020, the Minister of Health Terawan had approved province wide PSBB in Jakarta Province (approved on 7 April 2020), West Sumatra Province (17 April 2020), Gorontalo Province (28 April 2020), and West Java Province (1 May 2020), as well as PSBB in 37 regencies and cities. However, on 21 May 2020, the government announced that Indonesia had entered the new normal condition, relaxing the PSBB (Detik, 2020, May 21).

Meanwhile, in terms of economic mitigation, the government is implementing several social protections, tax stimulus and 
other economic measures. For example, on 31 March 2020 President Jokowi announced an additional state budget of IDR 405.1 trillion, of which IDR 75 trillion will be allocated for health expenditure, IDR 110 trillion for social protection, IDR 70.1 trillion for tax incentives and stimulus for people's business credit (KUR), and IDR 150 trillion for financing the national economic recovery program (Presiden RI, 2020, March 31). On 14 April 2020, the government announced exemption of value-added tax (PPN) and income tax (PPh) (Setkab, 2020, April 14). On 21 April 2020, President Jokowi announced the ban on mudik (homecoming to hometown or village during major holidays, especially Eid al-Fitr) (Presiden RI, 2020, April 21). On 22 April 2020, the Coordinating Minister for Economic Affairs, Airlangga, announced an additional tax stimulus of IDR 35.3 trillion for 18 sectors (Setkab, 2020, April 22).

\section{Discussion}

Amid the health response and economic mitigation, there are three characteristics of public health securitization that we can observe from the Indonesian government's measures to control the COVID-19 pandemic: (1) the over-reliance on influential military figures and national security actors, (2) the tendency to downgrade the threats, and (3) lack of transparency.

\section{Over-Reliance on Influential Military Figures and National Security Actors}

The over-reliance on influential military figures might come from the fact that there are several retired military and police figures in the current Indonesian cabinet. The military and police figures in the current cabinet were appointed at the start of this administration term before the COVID-19 pandemic and thus their appointment had nothing to do with the current securitization of the pandemic and more to do with political negotiations at the time. As Laksmana (2019a) has pointed out, Jokowi's reliance on those figures has been fueled by his need for support from the wider national security establishment to carry out his agenda. However, Yağanoğlu (2006, pp. 24-30) has argued that securitization is fed from prior militarization. Therefore, it is important to identify the military and police figures who had been influencing the government's decisionmaking process with military perspective since before the pandemic.

Arguably, the most influential military figure in the current cabinet is the Coordinating Minister for Maritime and Investment Affairs, Luhut Binsar Pandjaitan (hereinafter Luhut). He is a retired four-star general whose military service included the Army's Special Forces Command (Kopassus), where he became the founding commander of its counter-terrorism unit, Detachment 81 (now Sat-81/Gultor). His deputy at the time was Prabowo Subianto (hereinafter Prabowo), currently the Minister of Defense. Prabowo's peak military career included being the General Commander of Kopassus and Commander of the Army's Strategic Command (Kostrad). The Minister of Religious Affairs, Fachrul Razi (hereinafter Fachrul), is also a retired four-star general who was the Deputy Commander of TNI in 19992000. The Minister of Health, Terawan, was a military doctor who headed the Gatot Soebroto Army Hospital until his appointment in the current cabinet. The Chief of the Presidential Staff Office (KSP), Moeldoko, is another retired four-star general who was the Commander of TNI in 2013-2015. Meanwhile, the Minister of Home Affairs, Tito Karnavian (hereinafter Tito), is a retired police-general who was the Chief of Polri until his appointment in the current cabinet.

Several of these retired generals have used the grammar of security in describing the government's measures to the COVID-19 pandemic. For example, on 21 April 2020, when journalists asked why the government 
had only then decided to ban mudik, the Coordinating Minister for Maritime and Investment Affairs, Luhut, explained that the government decided to take gradual steps, which is "a military strategy" (Detik, 2020, April 21). The next day, when criticized for the lack of inter-ministerial coordination, Minister Luhut denied it saying he was "educated in the military", wherein there is tight coordination between the commanders and staff (Tribun News, 2020, April 22). Meanwhile, on 28 April 2020 the Minister of Defense, Prabowo, likened the government's measures to the COVID-19 pandemic to "a war against an invisible enemy which has no ideology and no other agenda than to threaten human safety" (Kumparan, 2020, April 28).

As Yağanoğlu (2006, pp. 24-30) again has argued, securitization enables the continuation of militarization. Similarly, the securitization of COVID-19 pandemic has strengthened the militarization by giving way to several military elements in the Indonesian government's measures to the COVID-19 pandemic. For example, the spokesman of COVID-19 Task Force, who was appointed on 3 March 2020, is the Secretary of the Directorate General of Disease Prevention and Control of the Ministry of Health, Achmad Yurianto (hereinafter Yurianto), who was also a military physician. Meanwhile, the government's COVID-19 Mitigation Acceleration Task Force, established on 13 March 2020, is led by the Chief of BNPB, Lt. Gen. Doni, who is an active three-star general whose military service included being the General Commander of Kopassus.

The COVID-19 Task Force which Lt. Gen. Doni leads is under and responsible directly to the President. It has a steering committee and an executive committee, with a secretariat at the BNPB. It was reorganized a week after its establishment and gained more ministries and agencies to increase coordination. It also coordinates local COVID-19 task forces established by local leaders (governors, regents, and mayors). The national Task Force also involves many military figures. Among the members of its steering committee are the retired military figures of the cabinet: Terawan, Tito, Prabowo, Fachrul, and Moeldoko. Aside from ministers, there are also Chief of the State Intelligence Agency (BIN) Budi Gunawan, Commander of TNI A.C.M. Hadi Tjahjanto, and Chief of Polri Pol. Gen. Idham Azis. Meanwhile, among those under Lt. Gen. Doni's command in the executive committee are the Operations Assistant of the Commander of TNI and the Operations Assistant of the Chief of Polri as deputy chairpersons. The organization of the COVID-19 Task Force is summarized in Table 4.

Meanwhile, the COVID-19 Task Forces at the local level also involve security actors. The task forces are led by governors at the province level and regents or mayors at the regency or city levels. As with the national COVID-19 Task Force, the military and police elements are appointed as deputy chairpersons of the local task forces. The organization of the local COVID-19 Task Force is summarized in Table 5.

At least three national security agencies are deeply involved in the government's COVID-19 measures: TNI, Polri and BIN. TNI's supposed role in the government's COVID-19 measures is to provide assets to support the COVID-19 Task Force in terms of logistics, supply and transport. By 11 April 2020, TNI was confirmed to have distributed medical equipment to all provincial capitals, led by the Deputy Operations Assistant of the Commander of TNI (Antara, 2020, April 11). On 23 March 2020, TNI announced the formation of four Integrated Joint Task Commands (Kogasgabad) as sub-units of the government's COVID-19 Task Force (Kompas, 2020, March 23). They were involved in the preparation of COVID-19 emergency hospitals in Kemayoran, Jakarta and Galang Island, Riau Islands. Meanwhile, Polri's supposed role is to enforce social distancing and other mitigation measures. On 19 March 2020, Chief of Polri, Pol. 
Table 4.

Organization of the Indonesian Government's COVID-19 Task Force

\begin{tabular}{|c|c|c|}
\hline Structures & 13-19 March 2020 & Since 20 March 2020 \\
\hline $\begin{array}{l}\text { Steering } \\
\text { Committee }\end{array}$ & $\begin{array}{l}\text { - Coordinating Minister for Human } \\
\text { Development and Cultural Affairs } \\
\text { - Coordinating Minister for Political, } \\
\text { Legal, and Security Affairs } \\
\text { - } \quad \text { Minister of Health } \\
\text { Minister of Finance }\end{array}$ & $\begin{array}{l}\text { - Chairperson: Coordinating Minister for Human } \\
\text { Development and Cultural Affairs } \\
\text { Deputy Chairpersons: } \\
\text { - Coordinating Minister for Political, Legal, and } \\
\quad \text { Security Affairs } \\
\text { - Secretary: Minister of Finance } \\
\text { - Members: Chief executives of } 26 \text { ministries and } \\
\text { agencies as well as governors throughout Indonesia }\end{array}$ \\
\hline $\begin{array}{l}\text { Executive } \\
\text { Committee }\end{array}$ & 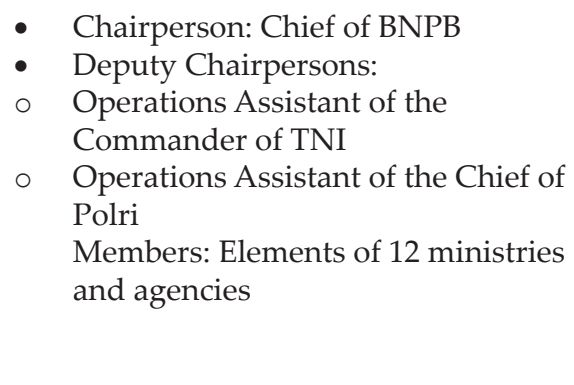 & $\begin{array}{l}\text { - Chairperson: Chief of BNPB } \\
\text { Deputy Chairpersons: } \\
\circ \text { Secretary General of the Ministry of Health } \\
\circ \quad \text { Secretary of the Minister of State-Owned } \\
\text { Enterprises } \\
\circ \quad \text { Secretary General of National Resilience } \\
\text { Council (Wantannas) } \\
\circ \quad \text { Operations Assistant of the Commander of TNI } \\
\circ \quad \text { Operations Assistant of the Chief of Polri } \\
\text { - Members: Elements of } 33 \text { ministries and agencies }\end{array}$ \\
\hline
\end{tabular}

Source: Presidential Decree No. 7 of 2020 and Presidential Decree No. 9 of 2020

Table 5.

Organization of the Local COVID-19 Task Forces

\begin{tabular}{lll}
\hline Structures & \multicolumn{1}{c}{ Province-Level } & Regency/City-Level \\
\hline Chairperson & Governor & Regent/Mayor \\
Deputy Chairpersons & $-\quad \begin{array}{l}\text { Commander of Regional Military } \\
\text { Command (Kodam) or Military Area } \\
\text { Command (Korem) }\end{array}$ & $\begin{array}{l}\text { Commander of Military District } \\
\text { Command (Kodim) or Military District } \\
\text { Command Sector (Koramil) }\end{array}$ \\
Secretariat & $\begin{array}{l}\text { Chief Regional Police (Polda) } \\
\text { (BPBD) }\end{array}$ & $\begin{array}{l}\text { Chief of Departmental Police (Polres) } \\
\text { Members }\end{array}$ \\
$\begin{array}{l}\text { Elements of various local government } \\
\text { offices and agencies }\end{array}$ & $\begin{array}{l}\text { Regional Disaster Management Agency } \\
\text { (BPBD) }\end{array}$ \\
\hline
\end{tabular}

Source: Minister of Home Affairs Circular No. 440/2622/SJ dated 29 March 2020

Gen. Idham Azis, issued Chief of Polri Notice No. Mak/2/III/2020 to prohibit social activities that could create crowds. Since then, until 12 April 2020, Polri claimed to have dissolved as many as 205,502 mass gatherings across the country (Kompas, 2020, April 13). Finally, BIN's supposed role is to conduct contact tracing to track the spread of COVID-19.

While the TNI, Polri, and BIN's involvement in the COVID-19 measures is necessary, soon their roles extend beyond the supposed roles. For example, TNI - not public health authorities - operates the COVID-19 emergency hospitals in Kemayoran, Jakarta and Galang Island, Riau Islands, despite the commanders having no medical background. However, it is fair to say that the TNI has not been the definitive leading actor of the COVID-19 measures. Evan A. Laksmana and Rage Taufika (2020) even argued that the TNI as an organizational actor was not yet fully mobilized, finding that the various TNI operations thus 
far in support of the government's COVID-19 measures only utilized a small number and localized military assets and personnel.

On the other hand, Polri's role extends to crackdown against criticism of the government. On 4 April 2020, Chief of Polri, Pol. Gen. Idham Azis, issued Telegram Letter No. ST/1100/IV/ HUK.7.1.2020 containing law enforcement guidelines in dealing with criminal activities amid the COVID-19 pandemic, which listed insult to the president and government officials as one of the crimes in cyberspace. They will use the Criminal Code (KUHP) Article 207 against offenders - a problematic article that is widely described as a "rubber provision", meaning that it can be broadly interpreted and tends to weaken human rights protection. On 13 April 2020, Polri said that there were already two people named as suspects of insulting the president (Antara, 2020, April 13). On April 23, the police arrested Ravio Patra, a public policy researcher and democracy activist who had been critical of the government, due to a message sent from his WhatsApp number, which he claimed was hacked (CNN Indonesia, 2020, April 23). He was freed the next day, after undergoing an investigation and being named a witness in the case. These crackdowns hint that the government is not only fighting the pandemic, but also defending the political regime.

BIN's extended role is arguably the most problematic. For example, on 13 March 2020, BIN announced that they had made a modelling of the spread of COVID-19, which predicted that the peak would occur in May, making intelligence data a public domain (Detik, 2020, March 13). On 6 April 2020, Chief of COVID-19 Task Force, Lt. Gen. Doni, announced that BIN's prediction on the number of COVID-19 cases was "99 percent accurate" (Tirto, 2020, April 6). Amid concern of a very low testing rate in Indonesia, there is a growing suspicion that the government is basing its testing rate on BIN's prediction.

Prior to the pandemic, BIN did not have an entity tasked with health intelligence. Amid the COVID-19 pandemic, BIN established a medical intelligence unit and recruited medical personnel volunteers for handling COVID-19, who were inaugurated on 22 April 2020. Since then, BIN has conducted several COVID-19 tests, including in Kendal Tunnel area, Central Jakarta (CNN Indonesia, 2020, May 6), and Dukuh Atas area, South Jakarta on 6 May 2020 (Okezone, 2020, May 6); in Blok M MRT Station, South Jakarta on 8 May 2020 (Viva, 2020, May 8); in Pondok Aren district, South Tangerang on 14-15 May 2020 (RMOL Banten, 2020, May 15); in several areas in Surabaya starting 29 May 2020 (Tribun News, 2020 May, 29); and in Ciledug CBD area, Tangerang on 31 May 2020 (Tribun News, 2020, May 30). Aside from conducting tests, BIN also sprayed disinfectants to several areas and educated the community on the dangers of COVID-19.

BIN's role in the COVID-19 measures is problematic because of three reasons: First, BIN did not have specialization in epidemiology and public health. Therefore, the fact that they made a modeling of COVID-19 is something that is out of their competence, let alone claiming that the prediction is accurate. Second, even if we assume that BIN has competence in making predictions of COVID-19, intelligence work should only be delivered to the President as a single client; it should be confidential and not open to the public. Therefore, the act of announcing their prediction of COVID-19 to the public is contrary to BIN's very essence as an intelligence agency. Third, as an intelligence agency, BIN's actions should be clandestine; its role in the COVID-19 measures is no exception. Therefore, even if they are conducting tests and other actions in public, BIN should not publicly put out their name and cover their acts on behalf of the name of other institutions.

\section{Tendency to Downgrade the Threats}

The over-reliance on influential military figures and the national security agencies might be related to the tendency of the Indonesian 
government to downgrade the COVID-19 threats. As previously described, at first the government denied experts' warning that the coronavirus might already exist undetected in Indonesia. Even after the pandemic has spread in Indonesia, the government still tries to minimize it by claiming that the virus will become weaker during the dry season. For example, on 2 April 2020, Coordinating Minister for Maritime and Investment Affairs, Luhut, said that the coronavirus could not survive in Indonesian hot weather (Kompas, 2020, April 2). It was followed by the Meteorology, Climatology, and Geophysical Agency (BMKG), which on 4 April 2020 announced that the agency's study confirmed that Indonesian weather and climate conditions and the archipelagic geography made the country at relatively lower risk of COVID-19 (BMKG, 2020). The Indonesian Medical Association (IDI) immediately declined the claim (Kompas, 2020, April 3), while subsequently the media also published fact-checking articles which deny it (Kumparan, 2020, April 3; Tempo, 2020, April 6; Tirto, 2020, April 8).

The tendency to downgrade the threats might also be observed from the limited efforts to contain the spread of COVID-19. Indonesia has a very low COVID-19 testing rate, with a total of 223,624 people tested or only 835 tests in every million people as of 31 May 2020 (Worldometer, 2020). According to the spokesman of COVID-19 Task Force, Yurianto, the low rate is due to the government not performing tests based on population size but on positive case contact tracking and on visits to health facilities by people with symptoms. To be fair, the testing rate has improved after the government prepared more PCR sample test laboratories, as announced on 13 April 2020 (Setkab, 2020, April 13).

Another indicator of the limited efforts is the Indonesian government's refusal to implement lockdown like in other countries. President Jokowi has argued that Indonesia's character is different from the countries which have succeeded doing lockdown (CNN Indonesia, 2020, March 24), and the government prefers the enforcement of physical distancing in public involving the TNI and Polri (Jakarta Globe, 2020, March 23). Meanwhile, Chief of COVID-19 Task Force, Lt. Gen. Doni, also announced that the central government considered the lockdown policy implemented by several other countries had failed (Liputan 6, 2020, March 30).

Even after several local governments such as Tegal, Tasikmalaya, and Papua announced local lockdowns, on 29 March 2020 the central government responded that the local lockdown had no legal basis (Kumparan, 2020, March 29 ), and the central government was still drafting a government regulation (PP) which regulates when local governments can set local quarantine (Kompas, 2020, March 27). Following that, on 30 March 2020 President Jokowi announced the implementation of large-scale social restrictions (PSBB) and strict physical distancing. If the situation worsens significantly, the government will declare a civil emergency (CNN Indonesia, 2020, March 30).

Even the implementation of PSBB policy is delayed by bureaucratic red tape because local governments may only apply the PSBB after receiving approval from the Minister of Health. For example, after the Jakarta government submitted proposal to apply the PSBB status in the province, the central government initially returned the proposal and asked them to complete several data, and only approved PSBB in Jakarta a week later, after being pressured by health experts (Tempo, 2020, April 8). Not all PSBB proposals have been approved: The Minister of Health had rejected the proposals of Rote Ndao Regency, Palangka Raya, Sorong, Bolaang Mongondow Regency, and Gorontalo City. According to the spokesman of COVID-19 Task Force, Yurianto, PSBB will only be approved if the region has 
become the epicenter area (Kompas, 2020, April 16).

\section{Lack of Transparency}

Finally, instead of upholding transparency of COVID-19 data in Indonesia, at first the Indonesian government deliberately withheld information. On 13 March 2020, President Jokowi argued that lack of transparency is necessary to prevent people from panicking (Presiden RI, 2020, March 13). The spokesman of COVID-19 Task Force, Yurianto, also said that the government indeed controls which information is provided to the public (Merdeka, 2020, March 17). A month after admitting the deliberate lack of transparency, finally on 13 April 2020, President Jokowi instructed that all COVID-19 data must be open for access (Presiden RI, 2020, April 13).

Despite the course correction after a month, the initial lack of transparency had eroded public trust. This happened because the COVID-19 data presented by the central government does not match some local governments' data. For example, the number of COVID-19 deaths in Banten and Jakarta on 20 March 2020 as announced by the central government and the respective provincial governments was different. Similarly, the number of COVID-19 cases in Yogyakarta on the same day as announced by the central government and the Yogyakarta government was also different (Detik, 2020, March 20). Initially, the spokesman of COVID-19 Task Force, Yurianto, argued that the difference was due to the central government grouping case data by province based on the location of the hospital where each patient was treated or died, not based on the address at the patient's ID card (Detik, 2020, March 20). However, the media kept scrutinizing the difference, especially in regard of COVID-19 mortality data in the Jakarta Province (Jawa Pos, 2020, March 30). Finally, the BNPB spokesperson acknowledged that the difference occurred because the data input from the Ministry of Health, which was referred by the COVID-19 Task Force, was also limited (Tempo, 2020, April 5).

As discussed above, since the first cases were confirmed in March 2020 the Indonesian government has securitized the COVID-19 pandemic. There are various forms of speech acts related to the COVID-19 pandemic in this period: assertive speech acts in the forms of statements and explanations of the data of COVID-19 in Indonesia; directive speech acts in the forms of orders and requests of PSBB and physical distancing, as well as the ban on mudik; commissive speech acts in the forms of vows and threats of sanctions for violation of PSBB order and the mudik ban; expressive speech acts in the forms of statements of "military strategy" and "war against an invisible enemy"; and finally declarations of various policies and regulations that the government took as measures to the pandemic. The speech acts are accompanied with emergency measures, including the reliance on military figures and national security actors, as well as lack of transparency. Unfortunately, the government's tendency to downgrade the threats limited the efficacy of their limited efforts to contain the spread of COVID-19. As of 31 May 2020, Indonesia recorded the second highest cases in Southeast Asia and the highest deaths (WHO, 2020).

It is fair to say that the audience did not accept the government's securitization of the COVID-19 pandemic due to lack of facilitating conditions. First, the government's grammar of security was complicated because of the tendency to downgrade the threats. Second, the government's social capital was low due to the lack of transparency. Third, the audience's condition was not ideal to accept the security discourse and justify the government's emergency measures to the pandemic (PSBB and physical distancing) because of the various human insecurities they faced amid the enforcement of those measures, 
including financial loss due to unemployment and hunger due to food insecurity.

Finally, it is important to note that the securitization of the COVID-19 pandemic is not typical of Indonesia, but a global phenomenon (Nunes, 2020; Daoudi, 2020). Scholars have also studied other governments' securitization of the COVID-19 pandemic at home, such as in Brazil (Hoffmann Pfrimer \& Barbosa Jr., 2020), the United Kingdom (Stott, West, \& Harrison, 2020), Hungary (Molnár, Takács, \& Harnos, 2020), China (Liu \& Bennett, 2020), as well as in regions such as Europe (Vankovska, 2020), the Middle East (Hoffman, 2020), and Southeast Asia (Baysa-Barredo, 2020).

In the Southeast Asian region, the Philippines experience provided arguably the most similar case with Indonesia. The Philippine government has also been overreliant on influential military and police figures in its COVID-19 response, as well as on national security agencies, especially the Armed Forces of the Philippines (AFP) and the Philippine National Police (PNP). Arguably even worse than the Indonesian case, the Philippine government has been criticized for violation of basic civil liberties and human rights in their COVID-19 measures (Vallejo Jr. \& Ong, 2020, p. 6). President Rodrigo Duterte infamously ordered AFP and PNP to shoot dead protesters who breached quarantine rules (Amnesty International, 2020), as well as other statements which undermined human security. Indeed, analysts have pointed out the similarity between Indonesia's and the Philippines' COVID-19 securitization and militarization (Chandran, 2020; Esmaquel II, 2020).

The comparison shows that Indonesia is not a unique case. However, Indonesia still provides a good case for the study of public health securitization, especially the COVID-19 pandemic, due to its geographical and population size as well as militarized government. With 17,508 officially listed islands, Indonesia is the world's largest island country in the world, making it arguably easier to restrict the spread of the coronavirus from one island with confirmed cases to other islands by measures like border closures. The military influence on the government should also make them more effective at restricting the pandemic spread with maximum coercion. Nevertheless, the virus persisted spreading to all major islands and 34 provinces. This makes the study of the Indonesian case, albeit not distinctive, still an important one.

\section{Conclusion}

As discussed above, the Indonesian government has been unable to respond proportionate to the threat of COVID-19 because, until February 2020, the government tried to de-securitize this pandemic, and only began viewing this issue as a threat after the first cases were confirmed in March 2020. Because the government was late in declaring COVID-19 as an existential threat to national security, the audience does not fully accept the government's securitization efforts because public trust in the government's measures was already low. In addition, the means of emergency action taken by the government against the threat of COVID-19 are also limited, disproportionate to the threat of the disease.

Meanwhile, the Indonesian government's securitization of COVID-19 has been characterized by the over-reliance on influential military figures and national security agencies, the tendency to downgrade the threats, lack of transparency, and even crackdown on anti-government smears. This finding shows that future studies should analyze how the number of military figures in the government influence the success or failure of securitization. In short, the government is bringing the COVID-19 measures under control of national security agencies, whose state security perspective prevails over health and epidemiological perspective. These security actors then are subordinating the human security dimension to the national security approach in 
the COVID-19 measures, which in turn restricting its very efficacy.

The Indonesian government needs to change their approach to COVID-19 measures and prioritize the human security dimension by not downgrading the threats and upholding transparency. The government also needs to restrict statements which complicate the communication of COVID-19 issues. The government also needs to restore public confidence by improving its COVID-19 measures. Finally, it helps to put the COVID-19 measures under control of public health agencies with expertise on health care and epidemiology - and not putting them under leadership of military figures in the first place.

\section{References}

'That's A Problem': Indonesia's Coronavirus Vulnerability Revealed. (2020, January 31). Sydney Morning Herald. Retrieved from https://www.smh.com.au/world/ asia/that-s-a-problem-ind onesia-scoronavirus-vulnerability-revealed20200130-p53wc9.html

'That's A Problem': Indonesia's Coronavirus Vulnerability Revealed. (2020, January 31). The Age. Retrieved from https:// www.theage.com.au/world/asia/thats-a-problem-indonesia-s-coronavirusvulnerability-revealed-20200130-p53wc9. html

Achmad Yurianto: Saya Tidak Berbohong, Cuma Mengatur Informasi. (2020, March 17). Merdeka. Retrieved from https:// www.merdeka.com/peristiwa/achmadyurianto-saya-tidak-berbohong-cumamengatur-informasi.html

Arifianto, A. R. (2009). The Securitization of Transnational Labor Migration: The Case of Malaysia and Indonesia. Asian Politics \& Policy, 1(4), 613-630. https://doi. org/10.1111/j.1943-0787.2009.01145.x

Baysa-Barredo, J. M. (2020, June 16). Problematizing the Securitization of
Covid-19 in Southeast Asia: A Necessary Step Towards an Inclusive, Rights-Centred Normal. SHAPE-SEA. Retrieved from https://shapesea.com/op-ed/covid-19/ problematizing-the-securitization-ofcovid-19-in-southeast-asia-a-necessarystep-towards-an-inclusive-rights-centrednormal/

Benarkah Cuaca Panas Bisa Hentikan Penyebaran Virus Corona? (2020, April 3). Kumparan. Retrieved from https://kumparan.com/kumparansains/ benarkah-cuaca-panas-bisa-hentikanpenyebaran-virus-corona-1t8jrfF6oMB

Benarkah Klaim Luhut Bahwa Corona Tak Kuat Bertahan di Cuaca Panas? (2020, April 8). Tirto. Retrieved from https://tirto.id/ benarkah-klaim-luhut-bahwa-coronatak-kuat-bertahan-di-cuaca-panas-eLAa BMKG. (2020, April 4). Pengaruh Cuaca dan Iklim Terhadap Pandemi COVID-19. Jakarta: Meteorology, Climatology, and Geophysical Agency of Indonesia. Retrieved from https://www.bmkg. go.id/press-release/? $p=$ pengaruh-cuacadan-iklim-terhadap-pandemi-covid19\&tag=press-release\&lang=ID

BNPB Blak-blakan Data Kasus Positif COVID-19 Tidak Sesuai. (2020, April 5). Tempo. https://nasional.tempo.co/read/1328220/ bnpb-blak-blakan-data-kasus-positifcovid-19-tidak-sesuai

Buzan, B., \& Wæver, O. (1997). Slippery? Contradictory? Sociologically Untenable? The Copenhagen School Replies. Review of International Studies, 23(2), 241-250. https:// doi.org/10.1017/S0260210597002416

Buzan, B., Wæver, O., \& de Wilde, J. (1998). Security: A New Framework for Analysis. London: Lynne Rienner.

C. A. S. E. Collective. (2006). Critical Approaches to Security in Europe: A Networked Manifesto. Security Dialogue, 37(4), 443-487. https://doi. org/10.1177/0967010606073085 
Chandran, N. (2020, June 15). The Pandemic Has Given Armies in Indonesia and the Philippines a Boost. Foreign Policy. Retrieved from https://foreignpolicy. com/2020/06/15/coronavirus-pandemicarmy-military-southeast-asia-boostindonesia-philippines-jokowi-duterteauthoritarianism/

Daoudi, S. (2020, April). The War on COVID-19: The 9/11 of Health Security? Policy Paper(PP 20 - 06). Rabat: Policy Center for the New South.

Data Corona Pemerintah Pusat dan Pemprov Berbeda, Kok Bisa? (2020, March 20). Detik. https://news.detik.com/berita/d-4947653/ data-corona-pemerintah-pusat-danpemprov-berbeda-kok-bisa

De Salazar, P. M., Niehus, R., Taylor, A., Buckee, C. O., \& Lipsitch, M. (2020). Using Predicted Imports of 2019-nCoV Cases to Determine Locations That May Not be Identifying All Imported Cases. MedRxiv. https://doi. org/10.1101/2020.02.04.20020495

Deputi BIN Ungkap Permodelan: Puncak Corona Diperkirakan di Bulan Puasa. (2020, March 13). Detik. Retrieved from https://news.detik.com/berita/d-4938262/ deputi-bin-ungkap-permodelan-puncakcorona-diperkirakan-di-bulan-puasa

Dikritik Soal Ojek Online dan Larangan Mudik yang Terlambat, Luhut Pandjaitan: Saya Lahir di Militer. (2020, April 22). Tribun News. Retrieved from https://kaltim. tribunnews.com/2020/04/22/dikritik-soalojek-online-dan-larangan-mudik-yangterlambat-luhut-pandjaitan-saya-lahirdi-militer

Diminta Beri Diskon Tiket Pesawat, Garuda Indonesia Masih Menghitung. (2020, February 7). Kabar Bisnis. Retrieved from https://www.kabarbisnis.com/ $\mathrm{read} / 2897448 /$ diminta-beri-diskontiket-pesawat-garuda-indonesia-masihmenghitung
Djalante, R., Lassa, J., Setiamarga, D., Sudjatma, A., Indrawan, M., Haryanto, B.,... Warsilah, H. (2020). Review and analysis of current responses To COVID-19 in Indonesia: Period of January to March 2020. Progress in Disaster Science, 6, 100091. https://doi. org/10.1016/j.pdisas.2020.100091

Dua Hari Rapid Test Digelar BIN, Belasan Warga Tangsel Positif Covid-19. (2020, May 15). RMOL Banten. Retrieved from https://www.rmolbanten.com/ $\mathrm{read} / 2020 / 05 / 15 / 17087 / D u a-H a r i-R a p i d-$ Test-Digelar-BIN,-Belasan-WargaTangsel-Positif-Covid-19-

Dua Orang di Jawa Barat Jadi Tersangka Hoaks Penghinaan Presiden. (2020, April 13). Antara. Retrieved from https:// www.antaranews.com/berita/1417599/ dua-orang-di-jawa-barat-jadi-tersangkahoaks-penghinaan-presiden

Elbe, S. (2002). HIV/AIDS and the Changing Landscape of War in Africa. International Security, 27(2), 159-177. https://doi. org/10.1162/016228802760987851

Elbe, S. (2006). Should HIV/AIDS be Securitized? The Ethical Dilemmas of Linking HIV/ AIDS and Security. International Studies Quarterly, 50(1), 119-144. https://doi. org/10.1111/j.1468-2478.2006.00395.x

Esmaquel II, P. (2020, August 13). Soldiers Trump Science in Pandemic Laggards Philippines, Indonesia. Rappler. Retrieved from https://rappler.com/newsbreak/indepth/soldiers-trump-science-pandemiclaggards-philippines-indonesia

Febrica, S. (2010). Securitizing Terrorism in Southeast Asia: Accounting for the Varying Responses of Singapore and Indonesia. Asian Survey, 50(3), 569-590. https://doi.org/10.1525/as.2010.50.3.569

Floyd, R. (2015). Extraordinary or Ordinary Emergency Measures: What, and Who, Defines the 'Success' of Securitization? Cambridge Review of International Affairs, 
1-18. https://doi.org/10.1080/09557571.20 15.1077651

FOTO: Tes Corona BIN di Terowongan Kendal DKI.(2020,May6).CNNIndonesia. Retrieved from https://www.cnnindonesia.com/ nasional/20200506142752-22-500687/fototes-corona-bin-di-terowongan-kendal-dki

Garrett, L. (2001). The Nightmare of Bioterrorism. Foreign Affairs, 80(1), 76-89.

Geri, M. (2018). Securitization and Autonomization in Turkey and Indonesia: A Brief History and Review of the Period of Democratization. In M. Geri, Ethnic Minorities in Democratizing Muslim Countries (pp. 79-120). Cham: Palgrave Macmillan.

Graham, B. (2008). World at Risk: The Report of the Commission on the Prevention of WMD Proliferation and Terrorism. New York: Vintage.

Gugus Tugas: 650 Ribu APD Hazmat Didistribusikan ke Seluruh Provinsi. (2020, April 11). Antara. Retrieved from https://www.antaranews.com/ berita/1416175/gugus-tugas-650-ribuapd-hazmat-didistribusikan-ke-seluruhprovinsi

Gunawan, A. B. (2017). Kontrol Sipil atas Militer dan Kebijakan Pertahanan di Indonesia Pasca Orde Baru. Jurnal Politik, 2(2), 197230. https://doi.org/10.7454/jp.v2i2.117

Hansen, L. (2012). Reconstructing Desecuritisation: The NormativePolitical in the Copenhagen School and Directions for How to Apply It. Review of International Studies, 38(3), 525-546. https:// doi.org/10.1017/S0260210511000581

Heinecken, L. (2003). Facing a Merciless Enemy: HIV/AIDS and the South African Armed Forces. Armed Forces \& Society, 29(2), 281-300. https://doi. org/10.1177/0095327X0302900207

Hoffman, A. (2020). The Securitization of the Coronavirus Crisis in the Middle East. In Project on Middle East Political Science,
The COVID-19 Pandemic in the Middle East and North Africa (pp. 10-14). Washington, D.C.: Project on Middle East Political Science.

Hoffmann Pfrimer, M., \& Barbosa Jr., R. (2020). Brazil's War on COVID-19: Crisis, Not Conflict-Doctors, Not Generals. Dialogues in Human Geography. https://doi. org/10.1177/2043820620924880

Huysmans, J. (1998). Security! What Do You Mean? From Concept to Thick Signifier. European Journal of International Relations, 4(2), 226-255. https://doi. org/10.1177/1354066198004002004

IDI Tegaskan Cuaca Panas Tak Bikin Mati Virus Corona di Tenggorokan. (2020, April 3). Kompas. Retrieved from https://nasional. kompas.com/read/2020/04/03/15324331/ idi-tegaskan-cuaca-panas-tak-bikin-mativirus-corona-di-tenggorokan

Indonesia Bersih dari Virus Corona, Ali Ngabalin: Covid-19 Tidak Berkembang Kuat di Negara Tropis. (2020, February 29). Tribun News. Retrieved from https://www. tribunnews.com/nasional/2020/02/29/ indonesia-bersih-dari-virus-corona-ali-ng Indonesia Has No Reported Coronavirus Cases. Is That the Whole Picture? (2020, February 11). The New York Times. Retrieved from https://www.nytimes.com/2020/02/11/ world/asia/coronavirus-indonesia-bali. html

Indonesia Readies Airline Subsidies Amid Virus Outbreak. (2020, February 20). AIN Online. Retrieved from https:// www.ainonline.com/aviation-news/airtransport/2020-02-20/indonesia-readiesairline-subsidies-amid-virus-outbreak

Indonesia Tegaskan Tak Akan Lockdown karena Ada Beberapa Negara Gagal. (2020, March 30). Liputan 6. Retrieved from https://www.liputan6.com/news/ $\mathrm{read} / 4215060 /$ indonesia-tegaskan-takakan-lockdown-karena-ada-beberapanegara-gagal 
Istana soal Tegal hingga Tasikmalaya Lockdown Lokal: Tak Ada Dasar Hukumnya. (2020, March 29). Kumparan. Retrieved from https://kumparan.com/kumparannews/ istana-soal-tegal-hingga-tasikmalayalockdown-lokal-tak-ada-dasarhukumnya-1t7DjicUjr

It is Not COVID-19': Indonesian Health Official Mixes up Disease and Virus. (2020, February 25). The Jakarta Post. Retrieved from https://www.thejakartapost.com/ news/2020/02/25/it-is-not-covid-19health-official-mixes-up-disease-an

Jokowi Ingin Pembatasan Sosial Skala Besar dan Darurat Sipil. (2020, March 30). CNN Indonesia. Retrieved from https://www.cnnindonesia.com/ nasional/20200330145024-20-488291/ jokowi-ingin-pembatasan-sosial-skalabesar-dan-darurat-sipil

Jokowi Ungkap Alasan Tak Tetapkan Lockdown Corona. (2020, March 24). CNN Indonesia. Retrieved from https://www.cnnindonesia.com/ nasional/20200324095851-20-486338/ jokowi-ungkap-alasan-tak-tetapkanlockdown-corona

Kelakar Menhub: Kita Kebal Corona karena Doyan Nasi Kucing. (2020, February 17). Retrieved from Republika. https:// republika.co.id/berita/q5ul4k409/kelakarmenhub-kita-kebal-corona-karenadoyan-nasi-kucing

Kemenhub. (2020, February 13). Terdampak Virus Corona, Pemerintah Dorong Pemberian Insentif Kepada Maskapai Penerbangan. Ministry of Transportation of Indonesia. Retrieved from http://dephub. go.id/post/read/terd ampak-viruscorona,-pemerintah-dorong-

Kemenkeu. (2020, February 26). Ini Rencana Tambahan Insentif Pariwisata untuk Maskapai, Agen Perjalanan dan Wisatawan Domestik. Ministry of Finance of Indonesia. Retrieved from https://www. kemenkeu.go.id/publikasi/berita/inirencana-tambahan-insenti

Kepala BNPB Ungkap Prediksi BIN: Mei 95.451 Positif Corona COVID-19. (2020, April 6). Tirto. Retrieved from https://tirto.id/ kepala-bnpb-ungkap-prediksi-bin-mei95451-positif-corona-covid-19-eLj7

Kraska, P. B. (2007). Militarization and Policing-Its Relevance to 21st Century Police. Policing: A Journal of Policy and Practice, 1(4), 501-513. https://doi. org/10.1093/police/pam065

Kurniawan, Y. (2018). The Politics of Securitization in Democratic Indonesia. Springer International Publishing.

Laksmana, E. A. (2019a). Civil-Military Relations under Jokowi: Between Military Corporate Interests and Presidential Handholding. Asia Policy, 26(4), 63-71. https://doi.org/10.1353/asp.2019.0047

Laksmana, E. A. (2019b). Reshuffling the Deck? Military Corporatism, Promotional Logjams and Post-Authoritarian CivilMilitary Relations in Indonesia. Journal of Contemporary Asia, 49(5), 806-836. https:// doi.org/10.1080/00472336.2019.1613556

Laksmana, E. A., \& Taufika, R. (2020, May 20). How "Militarized" is Indonesia's COVID-19 Management? Preliminary Assessment and Findings. CSIS Commentaries, pp. 1-7.

Lee, A. (2020). Online Hoaxes, Existential Threat, and Internet Shutdown: A Case Study of Securitization Dynamics in Indonesia. Journal of Indonesian Social Sciences and Humanities, 10(1), 17-34. https://doi.org/10.14203/jissh.v10i1.156

Liu, X., \& Bennett, M. M. (2020). Viral Borders: COVID-19's Effects on Securitization, Surveillance, and Identity in Mainland China and Hong Kong. Dialogues in Human Geography, 10(2), 158-163. https:// doi.org/10.1177/2043820620933828

Lockdown Still Not an Option for Indonesia: Chief Security Minister. (2020, March 
23). Jakarta Globe. Retrieved from https:// jakartaglobe.id/news/lockdown-still-notan-option-for-indonesia-chief-securityminister

Luhut: Dari Hasil Modelling, Virus Corona Tak Kuat Hidup di Cuaca Indonesia. (2020, April 2). Kompas. Retrieved from https://nasional.kompas.com/ $\mathrm{read} / 2020 / 04 / 02 / 15275601 /$ luhut-darihasil-modelling-virus-corona-tak-kuathidup-di-cuaca-indones

Ma'ruf Amin: Indonesia Terhindar Corona, Berkah Ulama Baca Doa. (2020, February 27). Tempo. Retrieved from https://nasional. tempo.co/read/1312782/maruf-aminindonesia-terhindar-corona-berkahulama-baca-doa

Mahfud MD (@mohmahfudmd).(2020, February 15). ALHAMDULILLAH' 243 WNI yg pulang dr Wuhan dan diobservasi 14 hr di Natuna dinyatakan brsh dr Corona. Dlm kelakarnya, Menko Perekonomian Airlangga bilang "Krn perizinan di Indonesia ber-belit2 maka virus corona tak bs masuk. Tp omnibus law ttg perizinan la. Twitter Account of Mahfud MD (@ mohmahfudmd). Retrieved from https://twitter.com/mohmahfudmd/ status/1228545879885221890

Mahfud Sebut Pemerintah Siapkan PP soal Ketentuan Karantina oleh Daerah. (2020, March 27). Kompas. Retrieved from https://nasional.kompas.com/ read/2020/03/27/17212441/mahfud-sebutpemerintah-siapkan-pp-soal-ketentuankarantina-oleh-daerah

Mahfud: RI Satu-satunya Negara Besar di Asia Tak Kena Corona. (2020, February 7). CNN Indonesia. Retrieved from https://www.cnnind onesia.com/ nasional/20200207194915-20-472750/ mahfud-ri-satu-satunya-negara-besar-diasia-tak-kena-corona
McInnes, C. (2006). HIV/AIDS and Security. International Affairs, 82(2), 315-326. https:// doi.org/10.1177/1354066111425258

McInnes, C. (2011). HIV, AIDS and Conflict in Africa: Why Isn't It (Even) Worse? Review of International Studies, 37(2), 485-509. https:// doi.org/10.1017/S0260210510000574

McInnes, C., \& Lee, K. (2006). Health, Security and Foreign Policy. Review of International Studies, 32(1), 5-23. https://doi.org/10.1017/ S0260210506006905

McInnes, C., \& Rushton, S. (2010). HIV, AIDS and Security: Where are We Now? International Affairs, 86(1), 225-245. https:// doi.org/10.1111/j.1468-2346.2010.00877.x

McSweeney, B. (1996). Identity and Security: Buzan and the Copenhagen School. Review of International Studies, 22(1), 81-93. https:// doi.org/10.1017/S0260210500118467

Memahami Beda Data Kasus Covid-19 Milik Pemprov DKI dan Pusat. (2020, March 30). Jawa Pos. Retrieved from https://www. jawapos.com/jabodetabek/30/03/2020/ memahami-beda-data-kasus-covid-19milik-pemprov-dki-dan-pusat/

Menkes Tantang Harvard Buktikan Virus Corona di Indonesia. (2020, February 11). CNN Indonesia. Retrieved from https://www.cnnindonesia.com/ nasional/20200211195637-20-473740/ menkes-tantang-harvard-buktikan-viruscorona-di-indonesia

Meyer, P. K., Nurmandi, A., \& Agustiyara, A. (2019). Indonesia's Swift Securitization of the Natuna Islands: How Jakarta Countered China's Claims in the South China Sea. Asian Journal of Political Science, 27(1), 70-87. https://doi.org/10.1080/02185 377.2019.1590724

Molnár, A., Takács, L., \& Harnos, É. J. (2020). Securitization of the COVID-19 Pandemic by Metaphoric Discourse During the State of Emergency in Hungary. International Journal of Sociology and Social Policy. https:// doi.org/10.1108/IJSSP-07-2020-0349 
Mudik Baru Dilarang Sekarang, Luhut: Itu Strategi Militer. (2020, April 21). Detik. Retrieved from https://finance.detik. com/berita-ekonomi-bisnis/d-4985170/ mudik-baru-dilarang-sekarang-luhut-itustrategi-militer

Naidu, M. V. (1985). Military Power, Militarism and Militarization: An Attempt at Clarification and Classification. Peace Research, 17(1), 2-10.

Neal, A. W. (2010). Exceptionalism and the Politics of Counter-Terrorism: Liberty, Security and the War on Terror. Abingdon: Routledge.

Ningtyas, I. (2020, April 6). [Fakta atau Hoaks] Benarkah Virus Corona Covid-19 Tidak Kuat dengan Cuaca di Wilayah Seperti Indonesia? Tempo. Retrieved from https:// cekfakta.tempo.co/fakta/719/fakta-atauhoaks-benarkah-virus-corona-covid-19tidak-kuat-dengan-cuaca-di-wilayahseperti-indonesia

Nunes, J. (2020). The COVID-19 Pandemic: Securitization, Neoliberal Crisis, and Global Vulnerabilization. Cadernos de Saúde Pública, 36(5), e00063120. https://doi. org/10.1590/0102-311x00063120

Pemerintah Kucurkan Rp 72 Miliar untuk Influencer Genjot Pariwisata Indonesia. (2020, February 26). Liputan 6. Retrieved from https://www.liputan6.com/news/ $\mathrm{read} / 4187754 /$ pemerintah-kucurkanrp-72-miliar-untuk-influencer-genjotpariwisata-indonesia

Pemerintah Telah Setujui PSBB di 11 Daerah. (2020, April 16). Kompas. Retrieved from https://nasional.kompas.com/ $\mathrm{read} / 2020 / 04 / 16 / 13084531 /$ pemerintahtelah-setujui-psbb-di-11-daerah

Pemerintah: New Normal Adalah Hidup Bersih-Sehat, Bukan Pelonggaran PSBB. (2020, May 21). Detik. Retrieved from https://news.detik.com/berita/d-5023063/ pemerintah-new-normal-adalah-hidupbersih-sehat-bukan-pelonggaran-psbb
Pemkot Gandeng BIN RI Gelar Rapid Test Massal dan Swab Test Warga Surabaya Secara Gratis. (2020, May 29). Tribun News. Retrieved from https://surabaya. tribunnews.com/2020/05/29/pemkotgandeng-bin-ri-gelar-rapid-test-massaldan-swab-test-warga-surabaya-secaragratis

Permana, R, Faris, A. F (2020, May 8). BIN Siapkan 500 Alat Rapid Test di MRT Blok M. Viva. Retrieved from https:/www.viva.co.id/ berita/nasional/1215251-bin-siapkan-500alat-rapid-test-di-mrt-blok-m

Philippines: President Duterte Gives "Shoot to Kill" Order Amid Pandemic Response. (2020, April 2). Amnesty International. Retrieved from https://www.amnesty. org/en/latest/news/2020/04/philippinespresident-duterte-shoot-to-kill-orderpandemic/

Pirages, D. (1997). Ecological Theory and International Relations. Indiana Journal of Global Legal Studies, 5(1), 53-63.

Polri Klaim Telah 205.502 Kali Bubarkan Massa Selama Wabah Covid-19. (2020, April 13). Kompas. Retrieved from https://nasional. kompas.com/read/2020/04/13/20275441/ polri-klaim-telah-205502-kali-bubarkanmassa-selama-wabah-covid-19

Prabowo: Kita Perang Lawan Musuh yang Tak Kelihatan dan Tak Punya Ideologi. (2020, April 28). Kumparan. Retrieved from https://kumparan.com/kumparannews/ prabowo-kita-perang-lawan-musuhyang-tak-kelihatan-dan-tak-punyaideologi-1tJOx9Kj5TM/full

Presiden RI. (2020, April 13). Perluas Cakupan Pemeriksaan Spesimen dengan Pengujian PCR. President of Indonesia. Retrieved from https://www.presidenri.go.id/siaranpers/perluas-cakupan-pemeriksaanspesimen-dengan-pengujian-pcr/

Presiden RI. (2020, April 21). Pemerintah Tetapkan Larangan Mudik di Tengah Pandemi Covid-19. President of Indonesia. 
Retrieved from https://www.presidenri. go.id/siaran-pers/pemerintah-tetapkanlarangan-mudik-di-tengah-pandemicovid-19/

Presiden RI. (2020, February 17). Presiden Jokowi Ingin Pariwisata Indonesia Mampu Lampaui Negara Tetangga. President of Indonesia. Retrieved from https://www.presidenri.go.id/siaranpers/presiden-jokowi-ingin-pariwisataindonesia-mampu-lampaui-nega

Presiden RI. (2020, February 20). Presiden Jokowi Dorong Peningkatan Realisasi Investasi untuk Gerakkan Perekonomian. President of Indonesia. Retrieved from https://www.presidenri.go.id/ siaran-pers/presiden-jokowi-dorongpeningkatan-realisasi-invest

Presiden RI. (2020, February 25). Presiden Harapkan Industri Pariwisata Ambil Peluang di Tengah Wabah Korona. President of Indonesia. Retrieved from https://www.presidenri.go.id/siaranpers/presiden-harapkan-industripariwisata-ambil-peluang-di-teng

Presiden RI. (2020, March 13). Langkah Pemerintah Tangani Pandemi Virus Korona. President of Indonesia. Retrieved from https://www.presidenri.go.id/ siaran-pers/langkah-pemerintah-tanganipandemi-virus-korona/

Presiden RI. (2020, March 31). Pemerintah Kucurkan Rp405,1 Triliun untuk Tangani Dampak Covid-19. President of Indonesia. Retrieved from https://www.presidenri. go.id/siaran-pers/pemerintah-kucurkanrp4051-triliun-untuk-tangani-dampakcovid-19/

Price-Smith, A. T. (2009). Contagion and Chaos: Disease, Ecology, and National Security in the Era of Globalization. Cambridge: The MIT Press.

Price-Smith, A. T. (Ed.). (2001). Plagues and Politics: Infectious Disease and International Policy. Hampshire: Palgrave.
Putus Mata Rantai Covid-19, BIN Gelar Rapid Test dengan Mobile Laboratorium. (2020, May 6). Okezone. Retrieved from https://nasional.okezone.com/ $\mathrm{read} / 2020 / 05 / 06 / 337 / 2210062 /$ putus-matarantai-covid-19-bin-gelar-rapid-testdengan-mobile-laboratorium

Ravio Patra Dikabarkan Ditangkap Polisi Usai Whatsapp Diretas. (2020, April 23). CNN Indonesia. Retrieved from https://www.cnnindonesia.com/ nasional/20200423110933-12-496447/ ravio-patra-dikabarkan-ditangkap-polisiusai-whatsapp-direta

Ross, A. L. (1987). Dimensions of Militarization in the Third World. Armed Forces \& Society, 13(4), 561-578. https://doi. org/10.1177/0095327X8701300405

Sarat, A. (2010). Sovereignty, Emergency, Legality. In A. Sarat (Ed.), Sovereignty, Emergency, Legality (pp. 1-15). Cambridge: Cambridge University Press.

Sasar Zona Merah, BIN Gelar Rapid dan Swab Test Massal di Tangerang. (2020, May 30). Tribun News. Retrieved from https://www.tribunnews.com/ metropolitan/2020/05/30/sasar-zonamerah-bin-gelar-rapid-dan-swab-testmassal-di-tangerang

Schofield, J. (2007). Militarization and War. New York: Palgrave Macmillan.

Searle, J. R. (1975). A Taxonomy of Illocutionary Acts. In J. R. Searle, Expression and Meaning (pp. 1-29). Cambridge: Cambridge University Press.

Sebastian, L. C., Syailendra, E. A., \& Marzuki, K. I. (2018). Civil-Military Relations in Indonesia After the Reform Period. Asia Policy, 25(3), 49-78. https://doi. org/10.1353/ASP.2018.0041

Setkab. (2020, April 13). Selain Perluasan Tes PCR, Ini 5 Arahan Presiden Terkini pada Gugus Tugas Covid-19. Cabinet Secretariat of Indonesia. Retrieved from https://setkab. go.id/selain-perluasan-tes-pcr-ini-5- 
arahan-presiden-terkini-pada-gugustugas-covid-19/

Setkab. (2020, April 14). Percepat Penanganan Covid-19, Pemerintah Berikan Insentif PPN dan PPh April-September 2020. Cabinet Secretariat of Indonesia. Retrieved from https://setkab.go.id/percepatpenanganan-covid-19-pemerintahberikan-insentif-ppn-

Setkab. (2020, April 22). Menko Perekonomian: Paket Stimulan Pajak Sektor Riil Diperluas. Cabinet Secretariat of Indonesia. Retrieved from https://setkab.go.id/ menko-perekonomian-paket-stimulanpajak-sektor-riil-diperluas/

Singh, J. (2016, October 7). Operation Tinombala: Indonesia's New Counter-Terrorism Strategy. Retrieved from RSIS Commentary No. 251: https://www.rsis.edu.sg/wp-content/ uploads/2016/10/CO16251.pdf

Stott, C., West, O., \& Harrison, M. (2020). A Turning Point, Securitization, and Policing in the Context of Covid-19: Building a New Social Contract Between State and Nation? Policing: A Journal of Policy and Practice. https://doi.org/10.1093/police/paaa021

Strongin, R. J., \& Redhead, C. S. (2001). Bioterrorism: Summary of a CRS/National Health Policy Forum Seminar on Federal, State, and Local Public Health Preparedness. Washington, D.C.: Congressional Research Service.

Tarik-Ulur Sebelum Pembatasan Berskala Besar. (2020, April 8). Tempo. Retrieved from https://koran.tempo.co/read/laporanutama/451656/tarik-ulur-sebelumpembatasan-berskala-besar

Thomas, V. F (2020, February 21). Corona Mereda, Luhut Mau TKA Cina Segera Masuk Lagi ke Indonesia.. Tirto. Retrieved from https://tirto.id/corona-meredaluhut-mau-tka-cina-segera-masuk-lagike-indonesia-eAoR

TNI Bentuk Komando Gabungan Tugas Terpadu, Atasi Covid-19 di 4 Wilayah.
(2020, March 23). Kompas. Retrieved from https://nasional.kompas.com/ $\mathrm{read} / 2020 / 03 / 23 / 13543531 /$ tni-bentukkomando-gabungan-tugas-terpadu-atasicovid-19-di-4-wilayah

Ullman, R. H. (1983). Redefining Security. International Security, 8(1), 129-153. https:// doi.org/10.2307/2538489

Vallejo Jr., B. M., \& Ong, R. A. (2020). Policy Responses and Government Science Advice for the COVID 19 Pandemic in the Philippines: January to April 2020. Progress in Disaster Science, 7(100115), 1-7. https:// doi.org/10.1016/j.pdisas.2020.100115

Van Damme, A. (2008, December). The Securitization of Terrorism in Indonesia: 2001-2006. Doctoral Dissertation. Vancouver: University of British Columbia.

Vanderveken, D. (2002). Universal Grammar and Speech Act Theory. In D. Vanderveken, \& S. Kubo (Eds.), Essays in Speech Act Theory (pp. 25-62). Amsterdam and Philadelphia: John Benjamins.

Vankovska, B. (2020). Dealing with COVID-19 in the European Periphery: Between Securitization and "Gaslighting". Journal of Global Faultlines, 7(1), 71-88. https://doi. org/10.13169/jglobfaul.7.1.0071

Virus Corona Makin Ganas, Menkes Bilang: Enjoy Aja! (2020, January 27). Warta Ekonomi. Retrieved from https://www. wartaekonomi.co.id/read268664/viruscorona-makin-ganas-menkes-bilangenjoy-aja

Vuori, J. A. (2008). Illocutionary Logic and Strands of Securitization: Applying the Theory of Securitization to the Study of Non-Democratic Political Orders. European Journal of International Relations, 14(1), 65-99. https://doi. org/10.1177/1354066107087767

Wæver, O. (1995). Securitization and Desecuritization. In R. D. Lipschutz (Ed.), On Security (pp. 46-86). New York: Columbia University Press. 
Wæver, O. (2000). The EU as a Security Actor. In M. Kelstrup, \& M. C. Williams (Eds.), International Relations Theory and the Politics of European Integration (pp. 250294). London: Routledge.

Wendt, A., \& Barnett, M. (1993). Dependent State Formation and Third World Militarization. Review of International Studies, 19(4), 321-347. https://doi. org/10.1017/S0260210500118248

WHO. (2020). WHO COVID-19 Dashboard. Retrieved from WHO: https://covid19. who.int/

Widiyono, Y. (2018, August). The Effect of Illicit Drugs Securitization in Indonesia. Master of Arts (MA) Thesis. Norfolk: Old Dominion University.

Williams, M. C. (2003). Words, Images, Enemies: Securitization and International Politics. International Studies Quarterly, 47(4),
511-531. https://doi.org/10.1046/j.00208833.2003.00277.x

Worldometer. (2020). Coronavirus Cases.

Retrieved from Worldometer: https://www.worldometers.info/ coronavirus/\#countries

Yağanoğlu, S. (2006, July). Securitization, Militarization and Gender in Turkey. A Master's Thesis. Ankara: Department of International Relations, Bilkent University.

Zayzda, N. A., Ash-Shafikh, M. H., \& Kusuma, A. S. (2019). Securitization and Desecuritization of Migration in Indonesia: Its Implication to Refugee Rights in the Southeast Asian Region. Journal of Southeast Asian Human Rights, 3(1), 81-100. https://doi.org/10.19184/ jseahr.v3i1.8394 